\title{
Studies on Periodic-Acid-Schiff Positive Substance in the Thymus of Mice
}

\author{
Kaoru Sagisaka \\ Department of Forensic Medicine (Prof. S. Akaishi), \\ Tohoku University School of Medicine, Sendai
}

\begin{abstract}
The present study deals with the distribution of periodic-acid-Schiff (PAS) positive substances in the thymus of dd-strain mice. The PAS-positive substances were found in about 15 per cent of the thymus lymphocytes in normal cases, and all of these cells were small thymic lymphocytes. In formalin stress, the substances disappeared just before morphological changes of the cells began to appear.

From a standpoint of the maturity of thymic lymphocytes investigated by means of tritiated thymidine, it was considered that the substances might develop in the cytoplasm in accordance with the growth of cells. Autoradiographs showed that labeled large thymic lymphocytes were transformed into PAS-positive labeled small ones with the lapse of time after the injection of isotope. Therefore, it is conceivable that thymic lymphocytes produce these substances in the immature stage of cells.
\end{abstract}

A number of studies by means of PAS technique, which was originally developed by McManus ${ }^{1}$ and Hotchikiss ${ }^{2}$ for the demonstration of glycogen, have been reported. Gibb and Stowell ${ }^{3}$ noted that PAS-positive substances were observed in the lymphocytes of peripheral blood. Wislocki et $a l^{4}{ }^{4}$ found that in patients with chronic lymphocytic leukemia, lymphocytes with these substances increased both relatively and absolutely. The presence of glycogen in thymic lymphocytes of young mice was reported by Smith and Thomas. ${ }^{5}$

The present study deals with PAS-positive substance of thymic lymphocytes in normal cases and in cases of formalin stress, and the development of these substances in the cells is discussed on the basis of autoradiography with tritiated thymidine.

\section{Material and Methods}

The animals used in this study were 22 to 23 days old dd-strain mice of both sexes, weighing about $10 \mathrm{~g}$.

Preparation of samples and PAS staining procedure. The animals were sacrificed by cervical dislocation, and the thymus was quickly excised. The sections were made from one lobe of the thymus. After fixation in Carnoy's solution

Received for publication, April 11, 1967. 
for 2 hours, the specimens were dehydrated, embedded in paraffin and cut to a thickness of $4 \mu$. Smears were prepared from the other lobe. The lobe was quickly placed in a Petri dish filled with Eagle agar at $37^{\circ} \mathrm{C}$, and it was gently teased with needles until the concentration of cell suspension became suitable for smear. The cell suspension were smeared with a small brush on chemically cleansed microscopic slides. The smear was fixed in methylalcohol for 10 minutes. All sections and smears were stained by the method of McManus. "Control sections and smears were treated in saliva solution at room temperature for 1 hour before PAS staining. After PAS staining, the sections were dehydrated in ascending series of alcohol, cleared in xylene and mounted with Bioleit. The smears were counterstained lightly with Giemsa in phosphate buffered saline at $\mathrm{pH} 5.8$.

Stress with formalin. The animals were injected intraperitoneally with 0.05 $\mathrm{ml}$ of $2 \%$ commercial formalin. They were sacrificed after 5,15 and 25 hours.

Autoradiographic procedure. The animals were injected intravenously with tritiated thymidine labeled nominally in the 6 -position $(8.6 \mathrm{Ci} / \mathrm{mM}$. The Radiochemical Centre, Amersham, England) at a rate of $1.5 \mu \mathrm{Ci}$ per g of body weight. They were sacrificed in 15, 25, 35, 55 and 80 hours. The smears stained with PAS technique and cleaned in distilled water were coated with Sakura NR-M1 autoradiographic emulsion (Konishiroku Photo Ind. Co. Ltd., Tokyo) by dipping method.? After 5 weeks' exposure, all slides were developed in $\mathrm{FD}-111$ at $20^{\circ} \mathrm{C}$ for 5 minutes and fixed in FF-H4 for 10 minutes. After washing in tap water, the smears were counterstained lightly with Giemsa solution.

\section{Results}

\section{PAS-positive thymic lymphocytes in the normal mice}

In the sections, PAS-positive substances were seen as fine red granules, and these were mostly digested in saliva. They were mainly distributed in deep areas of the cortex about 5 to 10 cell diameters apart from the capsule, and they were very few in the subcapsular zone of the cortex and the medulla. In the sections not treated with nuclear staining, the contour of cells was obscure and the distribution of granules was not definite. On the other hand, thymic lymphocytes in smears exhibited a number of small red dots in their cytoplasm, which were brilliantly stained and rather indistinctly outlined. The distribution patterns of PAS-positive substances were as follows: Fine granules were scattered uniformly in the cytoplasm (Fig. 5), located around the cell membrance as a ring (Fig. 6), or heavy clumps of granules dispersed frequently in the cytoplasm (Fig. 7). PAS-positive substances were found only in small thymic lymphocytes with scanty cytoplasm. Those were not found in large thymic lymphocytes over $10 \mu$ in diameter. About 15 per cent of all thymic lymphocytes had PAS-positive substances.

\section{The development of PAS-positive substance in the thymic lymphocyte}

The grains in autoradiographs were uniform in size and more distinct than the PAS-positive substance. The number of PAS-positive cell in autoradiograph 
TABLE 1. The labeling of thymic lymphocytes per 500 cells at various stages after the injection of tritiated thymidine

\begin{tabular}{|c|c|c|c|c|c|c|c|c|}
\hline Hrs & $\begin{array}{l}\text { Large } \\
\text { cell }\end{array}$ & $\begin{array}{c}\text { Labeled } \\
\text { large } \\
\text { cell }\end{array}$ & $\begin{array}{l}\text { PAS- } \\
\text { positive } \\
\text { large } \\
\text { cell }\end{array}$ & $\begin{array}{l}\text { Small } \\
\text { cell }\end{array}$ & $\begin{array}{l}\text { Labeled } \\
\text { small } \\
\text { cell }\end{array}$ & $\begin{array}{l}\text { PAS- } \\
\text { positive } \\
\text { small } \\
\text { cell }\end{array}$ & $\begin{array}{l}\text { Labeled } \\
\text { PAS- } \\
\text { positive } \\
\text { small } \\
\text { cell. }\end{array}$ & $\begin{array}{c}\text { Totel } \\
\text { labeled } \\
\text { cell }\end{array}$ \\
\hline 15 & 80 & 27 & 0 & 420 & 25 & 43 & 3 & 52 \\
\hline 25 & 72 & 17 & 0 & 428 & 26 & 47 & 6 & 43 \\
\hline 35 & 69 & 11 & 0 & 431 & 37 & 53 & 18 & 48 \\
\hline 55 & 75 & 4 & 0 & 425 & 47 & 51 & 29 & 51 \\
\hline
\end{tabular}

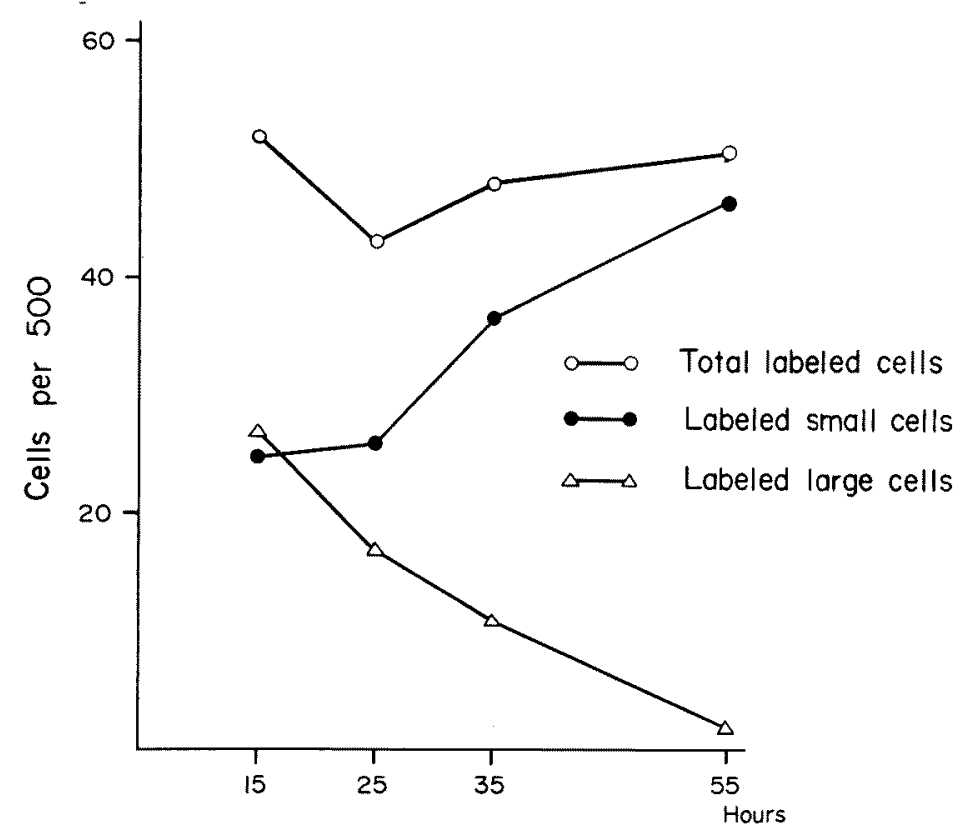

Fig. 1. The change of labeled thymic lymphocytes into small ones with the lapse of time after the injection of tritiated thymidine.

was not so many as that in smears stained simply with PAS technique. The active uptake of tritiated thymidine was noted in 34 per cent of the large lymphocytes 15 hours after the injection of the isotope (Fig. 8). In small thymic lymphocytes, the rate of labeling was relatively low. The labeling index of large thymic lymphocytes tended to decrease with the lapse of time after the isotope injection, but that of small thymic ones gradually increased. However, the total number of labeled cells in all thymic lymphocytes was almost the same. In the smears stained with PAS technique, 3 out of labeled 52 cells which were found in 500 examined cells were positive for PAS reaction 15 hours later. However, the peak in the incidence of PAS-positive cells in the total labeled cells was observed 55 hours later (Figs. 9 and 


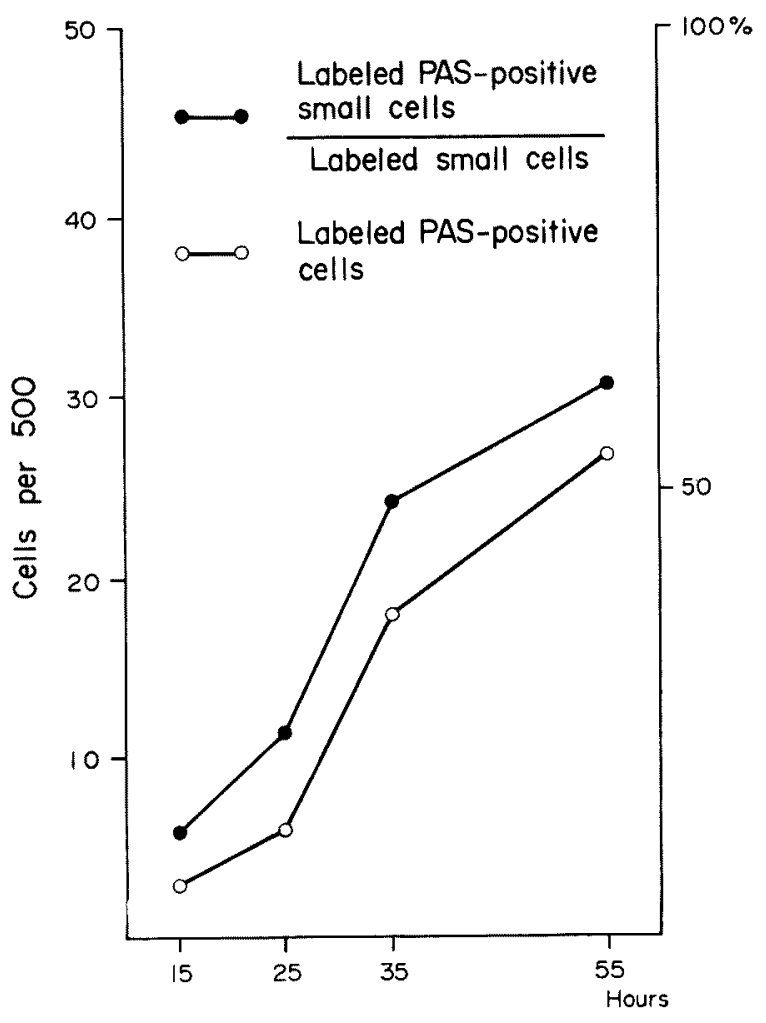

Fig. 2. The relationship of cell maturity with positive PAS reaction. Note PAS-positive reaction of almost all labeled cells 55 hours after the injection of tritiated thymidine.

TABLE 2. The change of PAS-positive thymic lymphocytes in stress per 1,000 cells

\begin{tabular}{cccc|ccc|c|c}
\hline Hrs & $\begin{array}{c}\text { Large } \\
\text { cell }\end{array}$ & $\begin{array}{c}\text { PAS- } \\
\text { positive } \\
\text { large } \\
\text { cell }\end{array}$ & $\begin{array}{c}\text { Small } \\
\text { cell }\end{array}$ & $\begin{array}{c}\text { PAS- } \\
\text { positive } \\
\text { small } \\
\text { cell }\end{array}$ & $\begin{array}{c}\text { Pyknotic } \\
\text { cell }\end{array}$ & $\begin{array}{c}\text { PAS- } \\
\text { positive } \\
\text { pyknotic } \\
\text { cell }\end{array}$ & $\begin{array}{c}\text { Total } \\
\text { PAS- } \\
\text { positive } \\
\text { cell }\end{array}$ \\
\hline Control & 159 & 0 & -537 & 152 & 4 & 0 & 152 \\
5 & 67 & 0 & 868 & 91 & 65 & 7 & 98 \\
15 & 43 & 0 & 506 & 71 & 451 & 16 & 87 \\
25 & 10 & 0 & 218 & 9 & 772 & 8 & 17 \\
& & & & & & & &
\end{tabular}

\section{0; Table 1).}

The change of PAS-positive granules in formalin stress

The animals fell into convulsion immediately after the injection of formalin solution. About 10 hours later, anorexia, the lack of motion, ruffed and unkempt fur, and diarrhea were seen. About one third of the animals died of exhaustion within 25 hours after the injection. Thymic lymphocytes began to show peculiar 


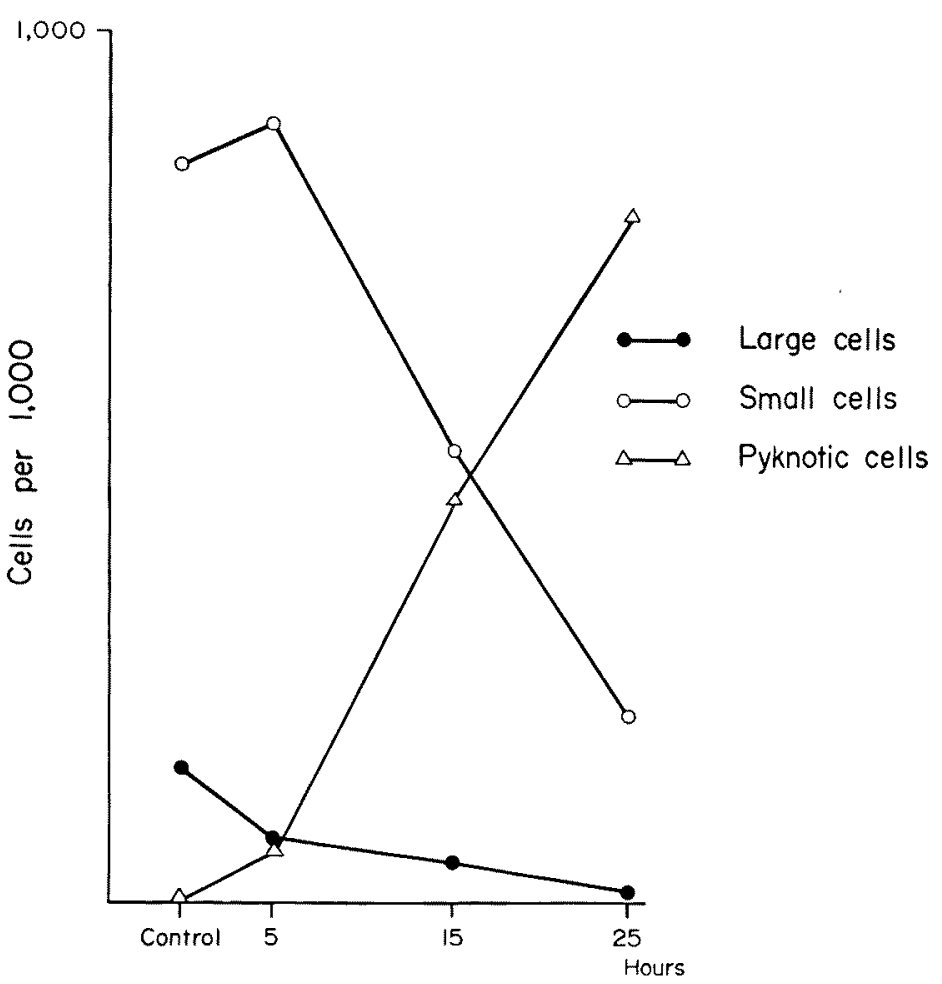

Fig. 3. The change of the thymic lymphocyte in formalin stress.

pyknosis 5 hours later, and a majority of the cells underwent morphological changes within 25 hours. It was noted that the pyknotic cells did not contain PAS-positive substance except for a few cells which contained heavy clumps of the substance (Fig. 11). Moreover, the percentage of PAS-positive cells in small thymic lymphocytes decreased remarkably in accordance with the aggravation of stress. In the stage of the strongest stress, PAS-positive substances were scarcely observed in the thymus (Table 2).

\section{Discussion}

In PAS reaction, the action of periodic acid depends on oxidation of carbohydrate compounds. Aldehydes formed by oxidation are detected by color reaction with the leucofuchsin of Schiff's reagent. A number of studies on various organs applying this reaction have been reported, but a few studies have been made on lymphoid tissues. From the study of blood film, Neukirch ${ }^{8}$ and Mancini and Gelani Barry ${ }^{9}$ agreed in that glycogen was not found in lymphocytes. Wachstein, ${ }^{10}$ Wislocki et $a l,,^{4}$ and Gibb and Stowell, ${ }^{3}$ however, reported that a few lymphocytes with PASpositive granules were found in human peripheral blood. Recently it was recog- 


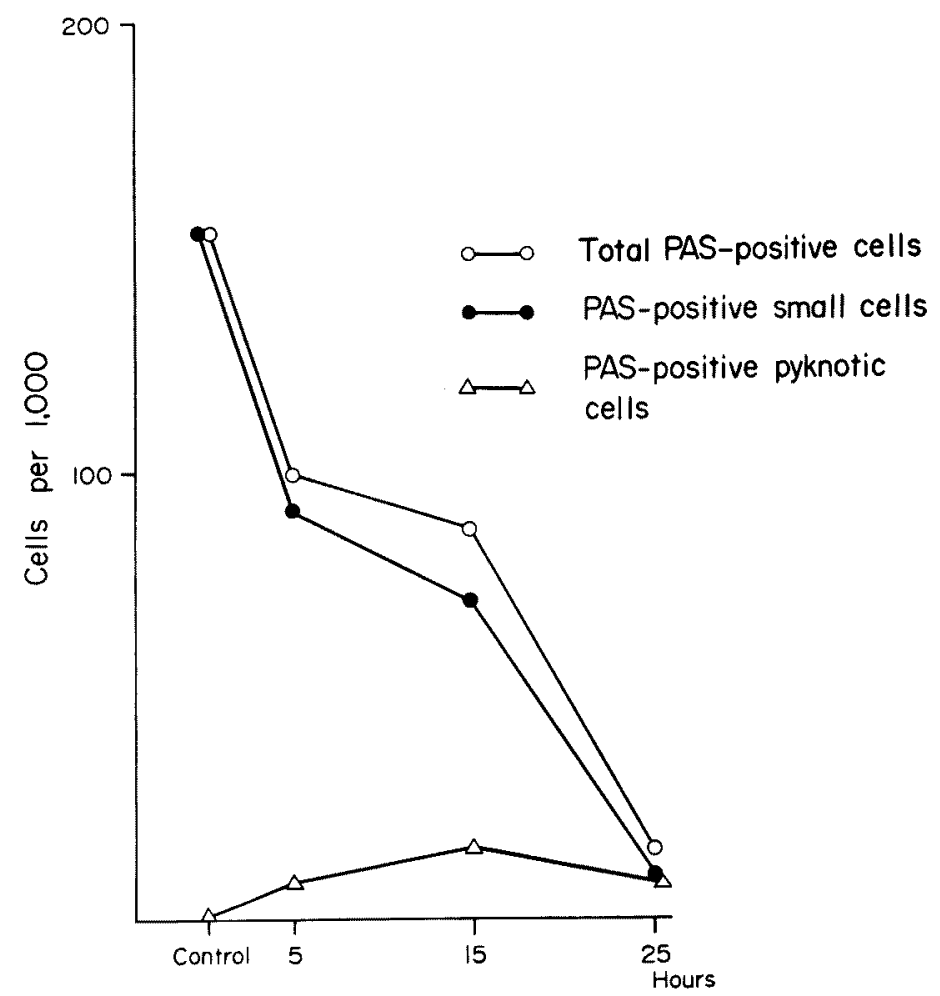

Fig. 4. The variation of PAS-positive thymic lymphocyte following the treatment with formalin.

nized in general that PAS-positive substance was contained also in peripheral lymphocytes.

Smith and Thomas" reported in a series of studies of the mammalian thymus that the cells containing glycogen were identified as small thymic lymphocytes but not as large ones in the thymic cortex, and a large number of cells with glycogen which were seen shortly after birth gradually decreased as the animals grew up.

In the present study, PAS-positive substance was seen only in small thymic lymphocytes, and in the deep cortex, but not in the subcapsular zone. This finding may support the view that thymic lymphocytes are formed in the subcapsular zone and migrate to deep cortex, where they are transformed into small ones.

According to Saint-Marie and Leblond, ${ }^{11}$ the generation time of lymphocytes in the thymic cortex of the rat is about 16 hours in large ones, 8 hours in mediumsized ones, and 67 hours in small ones. Fichtelius and Bryant ${ }^{12}$ reported that thymic lymphocytes migrated from the thymus to the lymphoid tissues after mitosis of about 8 times. The present study revealed that labeled large cells tended to be transformed into PAS-positive labeled small ones with the lapse of 
time after the isotope injection. This result may suggest that the substance develops at a relatively immature stage of the lymphocyte and the change from the large cell to the small one takes place in a short time. Eighty hours later the labeled cells could not be distinctly observed, because tritiated thymidine might have been transferred to the daughter cells by repeated mitosis, or the labeled cells might have migrated from the thymus to the lymphoid tissues. The PASpositive substance in the autoradiograph was less than that in a smear stained simply with PAS technique. It is considered that the substance was washed away in the course of photographical development and fixation.

Recently PAS-positive substance of peripheral lymphocytes in abnormal condition have been recognized by many investigators. Wislocki et al. ${ }^{4}$ found first that lymphocytes with PAS positive substances increased in patients with lymphocytic leukemia. Such abnormal increase of the cells in lymphocytotic disease was reported by Astaldi and Verga, ${ }^{13}$ Mitsu et al.., ${ }^{14}$ and Quaglino and Hayhoe. ${ }^{15}$ In view of the above relation between the maturity and PAS-positivity of the cells, the mechanism of increase in PAS-positive cells in deseases is interesting.

There has been little knowledge about the significance of PAS-positive substances in peripheral and thymic lymphocytes. Smith and Thomas ${ }^{5}$ found that thymic cells containing glycogen decreased as animals grew. They suggested that such a change of glycogen might correlate with dietary habit and growth, and that a relatively poor supply of oxygen might cause accumulation of glycogen. It seemed reasonable, however, to assume that the thymic lymphocytes might have important function in some metabolism, since PAS-positive substances were seen in small thymic lymphocytes predominating in thymic lymphocytes, and the substance developed in the cells at their relatively immature stage.

Metcalf and Ishidate ${ }^{16}$ reported that PAS-positive substance was frequently found in the reticulum cells of the thymus and the cells might stimulate the mitosis of thymic lymphocytes. According to the histological findings, however, the substance in reticulum cells seems to be essentially different from that of thymic lymphocytes.

In formalin stress, the change of PAS-positive substance was as apparent as the pyknosis of cells. It is very interesting that PAS-positive small cells decrease rapidly in stress, and the substance was scarcely observed in pyknotic cells. For this reason, the cytochemical changes due to stress may take place in advance of morphological ones. There have been many reports about the change of glycogen in various organs in stress. In the liver, glycogen diminishes during the first stage of stress presumably because blood sugar is supplied mainly from hepatic glycogen. It is well known that such phenomenon is caused by adrenaline. Therefore, it is considered that the diminution of PAS-positive substance in thymic lymphocytes depends upon enhanced adrenaline secretion or it is a premonitory process of pyknosis. Ohno ${ }^{17}$ stated that lymphocytes might discharge their own DNA to blood stream as a defence mechanism in stress. It was also observed by the present author that such a discharge of DNA occurred at the prepyknotic phase 
in the thymus. ${ }^{18}$ Accordingly, it may be concluded that a serious change in metabolism in the defence mechanism against the stress takes place in the thymic lymphocyte at the prepyknotic phase.

\section{Acknowledgment}

The author wishes to express his sincere gratitude to Prof. S. Akaishi and former Prof. T. Murakami for their guidance and advice.

\section{References}

1) McManus, J.F.A. Histological demonstration of mucin after periodic acid. Nature, $1946,158,202$.

2) Hotchikiss, R.D. A microchemical reaction resulting in the staining of polysaccharide structures in fixed tissue preparation. Arch. Biochem., 1948, 16, 131-141.

3) Gibb, R.D. \& Stowell, R.E. Glycogen in human blood cells. Blood, 1949, 4, 569-579.

4) Wislocki, G.B., Rheingold, J.J. \& Dempsey, E.W. The occurrence of the periodic acid-Schiff reaction in various normal cells of blood and connective tissue. Blood, 1949, 4, $562-568$.

5) Smith, C. \& Thomas, F.C. Studies on the thymus of the mammal, III. Glycogen in the cort.cal cells of the thymus. Anat. Rec., 1950, 106, 17-27.

6) McManus, J.F.A. \& Mowry, R.W. Staining methods, Hoeber Medical Division, New York, 1960, p.126.

7) Messier, B. \& Leblond, C.P. Preparation of coated radioautographs by dipping method in fluid emulsion. Proc. Soc. exp. Biol. Med. (N.Y.), 1957, 96, 7-10.

8) Neukirch, P. Úber die jodophile Substanz der Leukocyten und ihr Verhalten zur Bestschen Färbung. Ztschr. Klin. Med., 1910, 70, 251-256.

9) Mancini, R.E. \& Gelani Barry, R. Estudio critico del glucógeno en los leucocitos. Rev. Soc. argent. Biol., 1941, 17,499, cit. by R.D. Gibb and R.E. Stowell in: Glycogen in human blood cells. Blood, 1949, 4, 569-579.

10) Wachstein, M. The distribution of histologically demonstrable glycogen in human blood and bone marrow cells. Blood, 1949, 4, 54-59.

11) Saint-Marie, G. \& Leblond, C.P. Thymus-cell population dynamies. In: The Thymus in Immunobiology, edited by R.A. Good and A.E. Gabrielsen, Heober Medical Division, New York, 1964, p. 207.

12) Fichtelius, K.E. \& Bryant, B.J. On the fate of thymocytes. In: The Thymus in Immunobiology, edited by R.A. Good and A.E. Gabrielsen, Hoeber Medical Division, New York, 1964, p. 274.

13) Astaldi, G. \& Verga, L. The glycogen content of the cells of lymphatic leukaemia Acta haemat. (Basel), 1957, 17, 129-135.

14) Mitus, W.J., Bergan, L.J., Mednicoff, I.B. \& Bameshek, W. Cytochemical studies of glycogen content of lymphocytes in lymphatic proliferation. Blood, 1958, 13, 748756.

15) Quaglino, D. \& Hayhoe, F.G.J. Observation on the periodic acid-schiff reaction in lymphoproliferation diseases. J. Path. Bact., 1959, 78, 521-532.

16) Metcalf, D. \& Ishidate, M. PAS-positive reticulum cells in the thymus cortex of high and low leukaemia strains of mice. Austral. J. exp. Biol., 1950, 40, 57-71.

17) Ohno, K. The hormonal control of antibody production. Kagaku (Jap.), 1952, 22, $484-488$.

18) Sagisaka, K. Behavior of the thymus DNA in formalin stress. Igaku to Seibutsugaki (Jap.), 1967, 74, 80-84. 


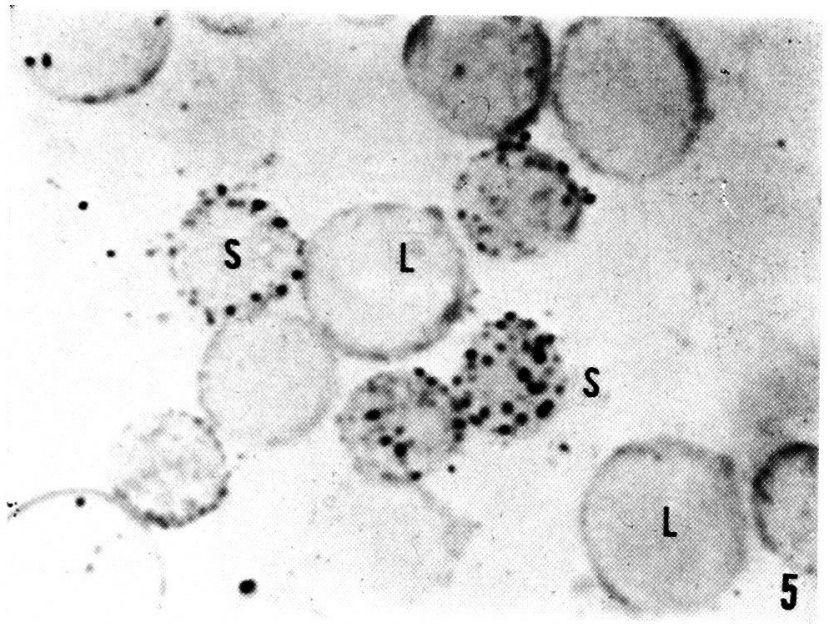

Fig. 5. Photomicrograph of PAS-positive substance scattered uniformly in the cytoplasm of small thymic lymphocytes (S) but not in large ones (L). $\times 1,500$.

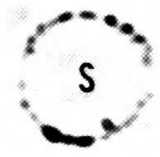

Fig. 6. PAS-positive substance located in the periphery of a small thymic lymphocyte (S). $\times 1,500$.

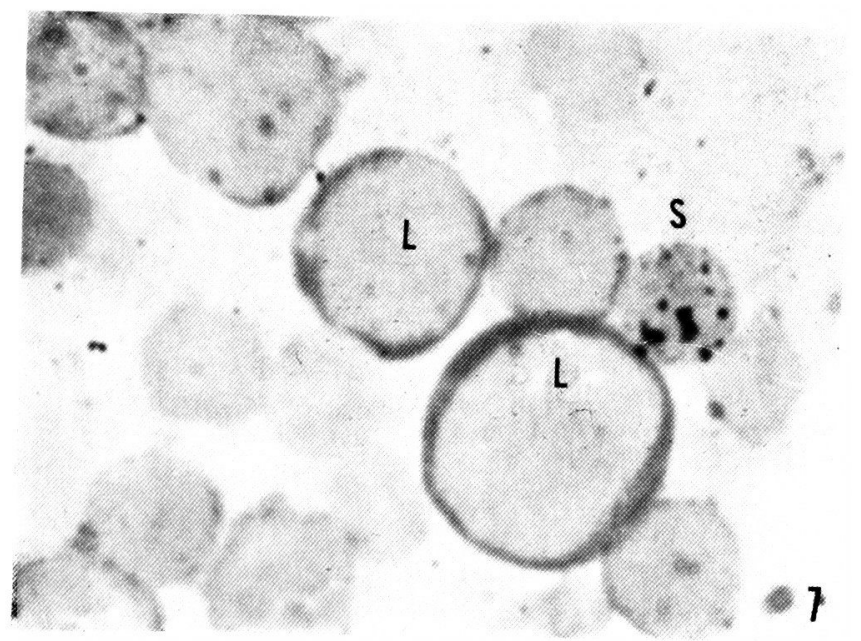

Fig. 7. A small thymic lymphocyte (S) with heavy clumps of PAS-positive granules. $\times 1,500$. 


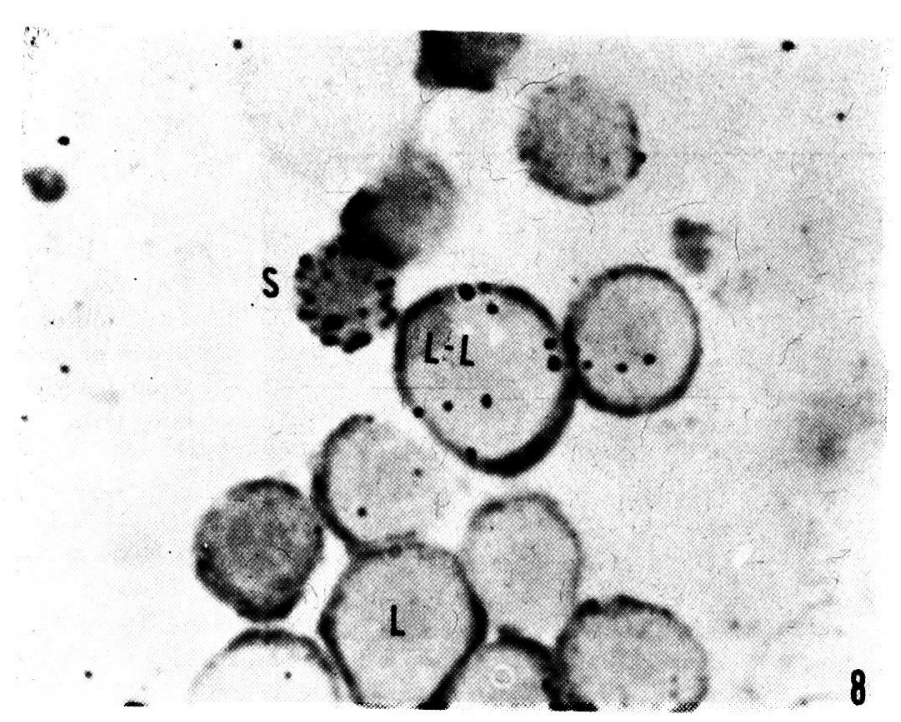

Fig. 8. Autoradiograph showing a l baled la"ge thymic lymphocyte (L-L). A small thymic lymphocyte with PAS-positive subs:ancs (S) is not labeled. Fifteen hours after the injection of tritiated thymidine. $\times 1,500$.

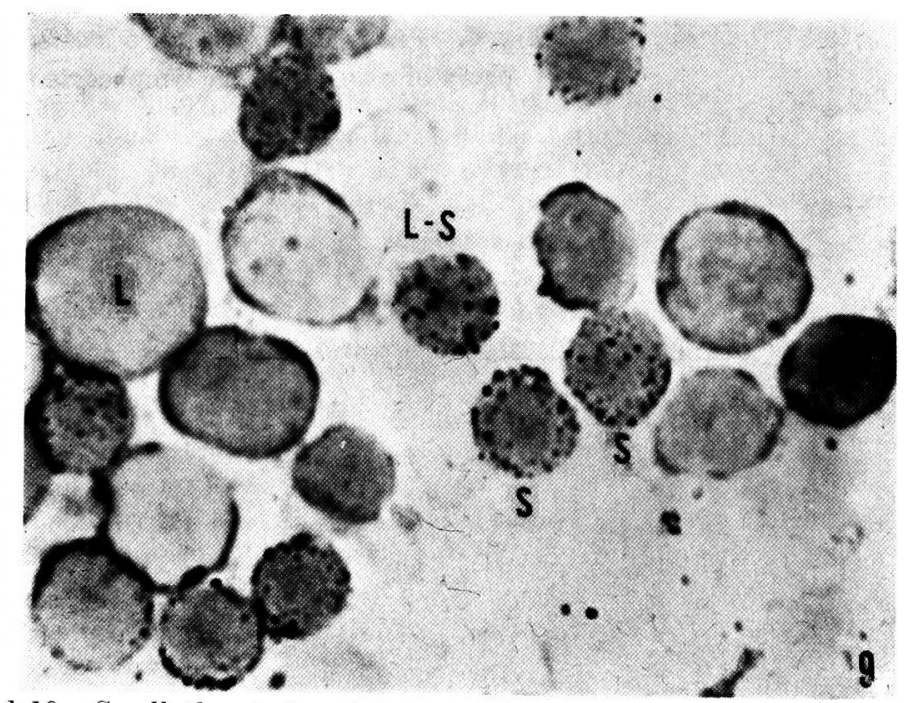

Figs. 9 and 10. Small thymic lymphocytes with PAS-positive substances (S) are labeled 55 hours later. Fig. 9 is focused on the cells, Fig. 10 on the grains. $\times 1,500$. 

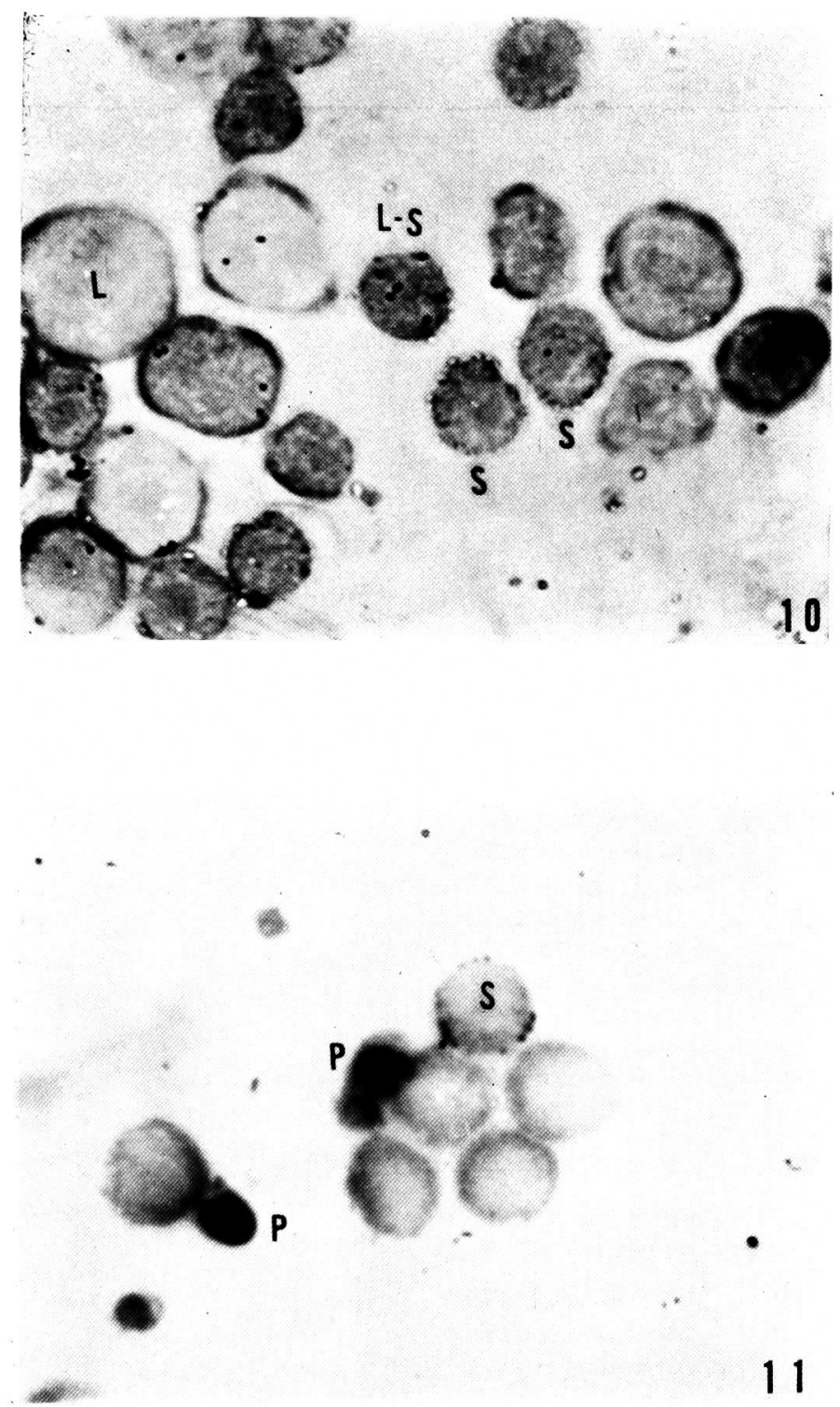

Fig. 11. PAS-positive substance in a small thymic lymphocyte (S) but not in pyknotic cells (P) 15 hours after formalin injection. $\times 1,500$. 